\title{
THE WEAK RELATION BETWEEN FOREIGN DIRECT INVESTMENT AND CORRUPTION: A THEORETICAL AND ECONOMETRIC STUDY
}

\author{
Tomáš Evan, Ilya Bolotov*
}

\begin{abstract}
:
Foreign direct investment has become an important factor of development of economies in the last decades. However, its economic nature as well as its relationship with corruption has not yet been clarified in economic literature. Following previous theoretical research, mainly Dunning's eclectic model, this paper evaluates the econometric relationship between corruption and foreign direct investment by testing three theoretically-based hypotheses: that corruption perception indicator is a stationary variable, that the relationship between corruption and foreign direct investment stock is statistically weak and that changes in foreign direct investment stock do not Granger cause changes in corruption. The verification is based on unit root tests, panel co-integration and Granger causality models performed on data from the Transparency International, the World Bank and the Heritage Foundation and the UN Conference on Trade and Development (UNCTAD) for 94 countries for the years $1998-2007$. The results show that there is no significant relationship between the two variables.
\end{abstract}

Keywords: corruption, foreign direct investment, Dunning eclectic model, unit root tests, panel co-integration, panel Granger causality test, Choi meta-tests

JEL classification: C12, C23, F21, F23

\section{Introduction}

Foreign direct investment (FDI) has become an important factor of development of economies in the last decades. Having numerous advantages, it has, however, not been proved to improve all aspects of the host country, especially its political environment. In this paper, we attempt to present a theoretical explanation and econometric verification of this fact on relation between corruption and FDI with the help of mainstream economic understanding of FDI and quantitative methods: unit root tests, panel co-integration models and panel Granger causality models.

The paper is divided into six parts beginning with the theoretical concept and ending with econometric results and general conclusion.

* Tomáš Evan, CIEE Prague and University of New York in Prague, Czech Republic (tomas_evan@, hotmail.com); Ilya Bolotov, University of Economics, Prague, Czech Republic (ilya.bolotov@vse.cz). This paper was elaborated in the framework of the VŠE IGS Research Project No. F2/5/2011,

"Importance of Financial Markets for International Business in a Globalized World Economy." 


\section{FDI from the Mainstream Economics' Point of View}

The approach presented in this paper is based on the assumption that the existence and size of multinational corporations (MNCs) is not caused by economic effectiveness, but by some sort of government-created market failure / subsidies, see e.g. Evan (2006 and 2010).

In general, MNCs have additional costs linked to their operations in more than one country, compared to domestic (local) companies. Hymer (1960 and 1976) was the first author to draw attention to the fact that, in order to offset these expenses, MNCs must have some kind of special advantages. In 1969, together with Charles P. Kindleberger, Hymer came up with a claim that the existence of foreign direct investment (FDI) is per se incompatible with a liberal market, as, otherwise, domestic companies would have been in a more favourable position, compared to MNCs in terms of costs. ${ }^{1}$

Before the Public Choice Theory constituted the concept of governmental failure, Hymer (1960 and 1976) and Kindleberger (1969) both stated that, as the competitive advantage of domestic companies does not materialize in the long-run and there is still plenty of thriving MNCs, some kind of a market failure must exist. Mainstream economists, in general, accepted this claim: e.g. Vernon and Wells (1972) and Caves (1982) used product life cycle theory as an explanation. However, profound incorporation of the idea into mainstream economics can be attributed to Dunning (1998) and his eclectic model of international production. In this paper, we follow Dunning's findings, particularly his definitions of two advantages of MNCs.

The first one is the advantage of the so-called "net ownership", which is internal for MNCs and is easily used in different countries. This advantage, such as trademarks, patents, know-how and other kinds of intellectual property, is crucial for MNCs. On the contrary, domestic companies do not possess such a benefit. The second one is the advantage of location, which depends on the character of the host country and is external for MNCs (it depends on the environment created by the host country's government through investment incentives schemes).

It is significant in the Dunning's concept that both advantages are of importance. Both are also dependent on governments of host countries and intergovernmental agreements and treaties, respectively. The length of the patent, the conditions of trade mark registration or license, the availability of monopoly over a certain resource or service, as much as tax holidays, financial or regulatory incentives, subsidized infrastructure are all forms of support available to MNCs, if agreed with the government of the host country. At the same time, the presence of MNCs is viewed by many politicians as an important

1 In 1969 the only rational explanation of this problem was the fact that MNCs, operating globally, could optimize their costs by a) achieving economies of scale and b) delocalizing their production and having a richer choice of suppliers. In this paper, we exclude both factors from our analysis, as it is not clear whether these factors are the cause or the effect (which is more likely) of MNCs special advantages. 
economic benefit and thus is supported; see e.g. the case of the Central and Eastern Europe.

Therefore, FDI seems to emerge more on political than economic (effectiveness-driven) basis and is linked to government interventions into the economy. If this relation had been broken, MNCs ceteris paribus would, most likely, be unable to pay for operations in various markets and would have to leave those markets, or, at least, they would face an important increase in costs and therefore in prices of their production. It is possible to state that MNCs are partly subsidized by governments, as in case of a protectionist trade policy; see Table 1 for comparison of the both.

Table 1

\section{Comparison of Negative Effects Caused by Protectionist Trade Policy and Investment Incentives}

\begin{tabular}{|l|c|c|}
\hline Negative effects caused by & tariffs and subsidies & investment incentives \\
\hline Sub-optimal allocation of capital & Yes & Yes \\
\hline High taxes & Yes & Yes \\
\hline Sub-optimal level of international trade & Yes & Yes \\
\hline Globally higher unemployment & Yes & Yes \\
\hline $\begin{array}{l}\text { Difficulty of international relation - economic } \\
\text { disputes among states }\end{array}$ & Yes & Yes \\
\hline Governments support mainly capital & domestic & foreign \\
\hline Global level of investment & decreases \\
\hline International trade & decreases & - \\
\hline Intra MNC trade (trade inside MNCs as groups) & - & rises \\
\hline
\end{tabular}

Source: Evan, 2006; self-prepared.

A logical summary of this theory can be found e.g. in Evan (2006 and 2010). Evan (2006) uses the notion "neomercantilism" for intense government intervention in favour of FDI due to its similarity to the corresponding trade policy (focus on the wealth of own country). ${ }^{2}$

\section{Relationship between FDI and Corruption}

It is often claimed that a good political environment, expressed e.g. by a democratic government and low corruption, is the main attraction for foreign direct investment (FDI). This opinion is still occasionally present in economic literature despite the fact there is little econometric evidence supporting it. Taking into account the above-presented theory, we are, however, more inclined to believe this claim not to be true for two main theoretical reasons.

2 It is important to stress that nowadays there is no regulation of this intervention at the intergovernmental level, as in case of the World Trade Organization for trade policy, which makes this comparison justifiable. 
Firstly, the claim is based on the assumption that, generally, a liberal investment climate is present in the FDI host countries, at least, in the developed world; see e.g. the UNCTAD World Investment Report (WIR). According to WIR, since 1991 there is a growing number of countries, which WIR denotes as liberalizing their investment regimes, and since 2004 it is over 100 countries every year. WIR, nevertheless, does not distinguish between legislature strengthening functions of the market (a liberal approach) and increasing investment incentives, e.g. in the form of co-financing, tax cuts, patents lasting several decades or research grants (a protectionist/government intervention approach). ${ }^{3}$ Investment incentives, however, do not necessarily have to be provided by democratic and corruption-free governments; see e.g. the case of the Soviet Union in the 1920s and 1980s and the recent increase in FDI inflows into China and Vietnam; and into Russia and other former USSR states, countries with a relatively high corruption.

Secondly, the nature of incentives as subsidies itself, strengthened by a stronger position of MNCs (there is more competition on the side of host countries over FDI than on the side of investors) leads to negotiations between MNCs and governments of the host countries, which may be subject to corruption and lobbyism, i.e. MNCs private or public offerings to politicians/governments in exchange for additional advantages. ${ }^{4} \mathrm{MNCs}$ affiliates in host countries may also unwillingly (in case of systemic corruption) or, in certain cases, even willingly (if acceptable in MNCs culture) participate in corruption practices.

The requirement of a good political environment may therefore be in practice compensated by government interventions (incentives) and by the culture of MNCs themselves, which may lead to weak or no relation between corruption and FDI.

\section{Previous Theoretical and Econometric Studies}

From the theoretical perspective, there is a large body of evidence of Dunning ownershiplocation advantages for different groups of countries. Lee and Mansfield (1996) in their comprehensive study proved for the case of the US MNCs, the largest investors in the world according to UNCTAD, a direct relationship between protection of intellectual property rights (IPRs) and receipts of unaffiliated royalties and licensing fees or incomes for the MNCs from FDIs in the host country. In the Czech Republic, a major FDI destination in the Central and Eastern Europe, there is also certain evidence supporting the link between investment incentive schemes presented or enlarged by the governmental agency CzechInvest and the increase in FDI inflow, see Dupal (2009). Petríček (2003) and Benáček (2010) also support the Dunning eclectic model, particularly the location advantage, with empirical evidence. Similar conclusions have been reached for Brazil,

3 Investment incentives in this respect usually represent additional "costs" for public finance, which further deteriorate existing budget deficits in some and lead to overall higher taxation in other countries.

4 Lobbyism in some forms can be considered as a legally acceptable form of corruption. 
Russia, India, China and South Africa (the BRICS countries), see Vijayakumar, Sridharan and Rao (2010) and WIR since 2000.

From the econometric perspective, there are several studies examining the relationship between corruption and FDI. Al-Sadig (2009) employs data for 170 countries over the period from 1984 to 2004 without finding any convincing evidence of correlation between the two variables (yet he insists that the results should not be interpreted as evidence that the corruption levels in the host country do not reduce FDI inflows). Caetano and Caleiro (2005) use a complex methodology and a fuzzy logic approach to create samples of countries with negative relationship between inward FDI performance and perceived level of corruption. By using data from 97 countries, they define two clusters, one with high level corruption countries, where corruption is negatively correlated with FDI, and the second, formed by low level corruption countries, where the influence is not so evident. They suggest that when a country is not included in the high corruption cluster, the FDI are influenced by other factors. Another group of researchers states that there is no systematic relationship: e.g. Harrison (2003) shows that certain corrupt low potential countries are able to attract FDI inflows while others are not. In total, there is little empirical evidence of a strong negative link between CPI and FDI inflows in economic literature, which supports the theoretical assumptions.

\section{Econometric Approach Developed in this Paper}

In this paper, we examine the relationship between corruption, measured by a corruption perception indicator/index (CI), and foreign direct investment stock in a country in relative terms (FDI stock), as a measurement of long-term FDI inflows, on a panel dataset.

From the above presented theory and previous econometric studies on the topic, it is perceivable that the relationship between CI and FDI stock should be relatively weak due to the compensation effect created by investment incentives and MNCs culture, which will be the base of our hypothesis. However, the absence/weakness of an economic relationship can be econometrically expressed in more than one way. In general, it is possible to distinguish between four possible econometric relationships between $\mathrm{CI}$ and FDI stock; see Table 2 . 
Table 2

Possible Econometric Relationships between CI and FDI Stock, Arranged from the Weakest to the Strongest

\begin{tabular}{|l|l|l|}
\hline Econometric relation & Interpretation & Hypothesis \\
\hline $\begin{array}{l}\mathrm{Cl} \text { is stationary and cannot be } \\
\text { influenced by non-stationary FDI stock } \\
\text { in the long run. }\end{array}$ & $\begin{array}{l}\text { Corruption is not influenced by any } \\
\text { external factors in the long run and is } \\
\text { fluctuating around a certain value. }\end{array}$ & $\begin{array}{l}\text { Stacionarity } \\
\text { Condition, SC }\end{array}$ \\
\hline $\begin{array}{l}\mathrm{Cl} \text { is non-stationary and } \mathrm{Cl} \text { and FDI } \\
\text { stock are weakly correlated. }\end{array}$ & $\begin{array}{l}\text { Corruption is influenced by external } \\
\text { factors, however, not significantly by FDI. }\end{array}$ & $\begin{array}{l}\text { Weak Correlation } \\
\text { Condition, WCC }\end{array}$ \\
\hline $\begin{array}{l}\text { Cl is non-stationary and Cl and FDI } \\
\text { stock are strongly correlated, but } \\
\text { changes in Cl are not Granger caused } \\
\text { by changes in FDI stock. }\end{array}$ & $\begin{array}{l}\text { Corruption is influenced by external } \\
\text { factors and is significantly correlated } \\
\text { with FDI, however, there are other } \\
\text { factors causing changes in the two } \\
\text { variables. }\end{array}$ & $\begin{array}{l}\text { No Causality } \\
\text { Condition, NCC }\end{array}$ \\
\hline $\begin{array}{l}\text { Cl is non-stationary, significantly related } \\
\text { to FDI stock and changes in Cl are } \\
\text { Granger caused by changes in FDI } \\
\text { stock. }\end{array}$ & $\begin{array}{l}\text { FDI has an important impact and } \\
\text { improves political environment in } \\
\text { countries. }\end{array}$ & \\
\hline
\end{tabular}

Note: FDI stock can be considered non-(constant)stationary due to the existence of a time trend in most countries. Source: self-prepared.

From the table it is perceivable that the first three cases represent the absence / weakness of relationship between CI and FDI stock and the last one - a significant relation. Therefore, we will have to test three interrelated hypotheses: SC, WCC and NCC. This will help to determine the type of the econometric relationship between corruption and FDI.

\section{Testing SC hypothesis - methodology}

In the theory of statistics, see e.g. Arlt (1999), the definition of stationarity (weak stationarity / short memory $)^{5}$ of a time series $\left(X_{t}\right)$ consists of three simultaneous conditions for all $t, k, h$ and $m$ :

1) The variation of $X_{t}$ is finite, $E\left(X_{t}^{2}\right)<\infty$;

2) The expectation of $X_{t}$ is finite and does not depend on $t, E\left(X_{t}\right)=E\left(X_{t+k}\right)=\mu<\infty$;

3) The covariance between $X_{t+m}$ and $X_{t}$ depends only on $m$ and does not depend on $t$, $\operatorname{COV}\left(X_{t+m}, X_{t}\right)=\operatorname{COV}\left(X_{t+m+h}, X_{t+h}\right)$.

Non-stationarity or integration of degree $d$, of the time series, i.e. $X_{t}$ (presence of the unit root/long memory), is then the case when only the $d$-th difference of $X_{t}\left(\Delta^{d} X_{t}\right)$ fulfills the criteria of stationarity (in this paper, we will work mostly with the first differences).

$5 \quad$ Hereafter, by using the term "stationarity", we will refer to the weak stationarity. The term strict or strong stationarity will be reserved for processes like independent and identically distributed random variables (iid). 
To test the SC hypothesis and obtain accurate results, we use two unit root tests on CI: the augmented Dickey and Fuller (1979), ADF, test and the Kwiatkowski-PhillipsSchmidt-Shin (1992), KPSS, test. ${ }^{6}$ Both tests include a constant and no time trend (as stated in $\mathrm{SC}$ ).

As the ADF and KPSS tests are applicable only to time series, to estimate the degree of integration ( 0 is stationarity, 1 and higher - unit roots) of panel data, their results for cross-sections have to be assessed with the help of another method. In this paper, we use Choi's (2001) meta-analysis where the overall (composite) p-value is calculated from the $\mathrm{p}$-values of ADF tests and p-value range estimations of KPSS tests in individual cross-sections.

Panel data can be then considered stationary and SC proved, if the overall p-value is lower (in case of the ADF test) or higher (in case of the KPSS test) than 0.01, 0.05 and 0.1.

\section{Testing WCC hypothesis - methodology}

To test the WCC hypothesis for a single year or cross-section, it would be sufficient to use a standard Pearson (product-moment) correlation coefficient (PCC), ${ }^{7}$ which varies from -1 to 1 inclusively, as a measurement of linear dependence between CI and FDI stock.

In a panel dataset, time or cross-sectional variation of PCC values can, however, be important, thus an estimation of a functional relationship is preferable. For this purpose we use a panel co-integration regression model (i.e. with correction for spurious relationships).

A panel co-integration model is a modification of the time series co-integration model, see e.g. Engle and Granger (1987) and Arlt (1997), and can be defined as a regression model where a) dependent and explanatory variables (regressors) are integrated of the same degree (at least 1) and b) the residuals are stationary. ${ }^{8}$ The model can be defined in the following form for unobserved/pooled and random effects (in this paper, we omit fixed effects, see below):

$$
\begin{gathered}
C I_{i, t}=\beta_{0}+\beta_{1} F D I_{-} \text {stock }_{i, t}+\varepsilon_{i, t} \\
C I_{i, t}=\beta_{0}+\beta_{1} F D I_{-} \text {stock }_{i, t}+v_{i}+\varepsilon_{i, t}
\end{gathered}
$$

where $i$ and $t$ stand for the cross-sections and corresponding years and $v_{i}$ for random effects.

6 Unlike other hypothesis testing, there is no single methodology for verifying the presence of unit roots in time series. Therefore, it is always advisable to use more than one test. ADF and KPSS also have different logic: the $\mathrm{H} 0$ hypothesis of the ADF test is the presence of a unit root in the time series, whilst the $\mathrm{H} 0$ of the KPSS test is the time series' stationarity.

7 This would include eventual de-trending for time series.

8 In the approach developed by Engle and Granger, in order to form a co-integration relationship, the residuals of a regression model need to be integrated in a lower degree than the dependent and explanatory variables. In econometric relationships, however, the condition of zero integration is more frequently used. 
Due to the absence of single approach to panel unit root testing, panel co-integration techniques also vary among authors. The latest important contribution to this problem was made e.g. by Kao (1999).

In this paper, we refer to the Choi's (2001) meta-analysis approach under the assumption that cross-sections in CI and FDI stock are almost homogenously integrated to the same degree and that the residuals of the model are almost homogenously stationary. This enables Choi's meta test to be an accurate measurement of co-integration relationships with a small degree of mistakes (presence of non-cointegrated relationships between panel datasets).

Provided this assumption holds, WCC will be proved, if SC is true or there is co-integration between $\mathrm{CI}$ and FDI stock and a) the $\mathrm{R}^{2}$ of the pooled regression is relatively small and/ or b) the regression coefficient of FDI stock is not statistically significant (p-value is greater than 0.1).

\section{Testing NCC hypothesis - methodology}

To test the NCC hypothesis, we use a panel Granger causality test (an F-test of relationship between the dependent variable and lagged values of an explanatory variable) for first differences in CI and FDI stock under the condition of their stationarity (which is a requirement of the test). This method was developed by Granger (1969) for time series data.

The panel version of the Granger test is relatively new to econometrics and is still in process of development. The main contributors to this topic are Hurlin and Venet (2001), Hurlin (2004a and 2004b) and Hurlin and Dumitrescu (2012) and e.g. Hood, Kidd and Morris (2006), as well as several other authors.

The model can be expressed in the following form under the assumption of equal number of lags $(k)^{9}$ for all variables for unobserved / pooled effects and random effects (fixed effects are omitted, see below):

$$
\begin{gathered}
\Delta C I_{i, t}=\beta_{0}+\sum_{j=1}^{k} \beta_{j} \Delta C I_{i, t-j}+\sum_{h=1}^{k} \gamma_{h} \Delta F D I_{-} \text {stock }_{i, t-h}+\varepsilon_{i, t} \\
\Delta C I_{i, t}=\beta_{0}+\sum_{j=1}^{k} \beta_{j} \Delta C I_{i, t-j}+\sum_{h=1}^{k} \gamma_{h} \Delta F D I_{-} \text {stock }_{i, t-h}+v_{i}+\varepsilon_{i, t}
\end{gathered}
$$

where $i$ and $t$ stand for cross-sections and years and $k$ for the number of lags.

The main problem of the panel Granger causality models is the absence of a single method of overall causality assessment. Hurlin (2004b) proposes a $\chi^{2}-$ test based on the average

9 We will use this frequently applied restriction due to the small number of years in panel data, see below. 
Wald (1943) statistic, ${ }^{10}$ which is, in fact, very similar to Choi's (2001) meta-analysis approach. However, as this test is not part of standard statistical software packages, it requires manual computing of Wald statistics for each cross section, which becomes difficult in bigger datasets (as in our case, see below).

In this paper we will therefore refer to the general logic of relationships between dependent variable and regressors in a panel regression (as Granger causality test is based on a standard regression model) by comparing between-group and total variance. A relatively low share of between-group variance (less than .5) will enable the overall Wald test to be considered a relatively accurate estimation of the overall causality (homogenous causality or non-causality, HC and HNC, Hurlin and Venet, 2001), otherwise we can speak of a mixed, difficultly interpretable result (heterogeneous causality or non-causality, HEC and HENC).

The NCC will be proved when SC and WCC are true or a) the conditions for the overall Wald test are met (otherwise, the results will be difficult to interpret) and b) coefficients of lagged changes in FDI stock are not statistically significant.

\section{Problem of corruption indicator estimation and data availability}

Calculations of the SC, WCC and NCC hypotheses also need to be adjusted to two problems.

Firstly, CI unlike FDI stock is calculated on the basis of surveys and therefore is a subjective measure of corruption whose estimates may vary among institutions. Therefore, to obtain robust results, we use CIs from three different sources: the Transparency International's Corruption Perception Index (CPI), the World Bank Control of Corruption Indicator (COC), a part of the Worldwide Governance Indicators (WGI) database, and the Heritage Foundation's Freedom from Corruption Index (FFC), and a part of the Index of Economic Freedom (IEF).

For FDI stock, we use the data from the UN Conference on Trade and Development (UNCTAD) UnctadStat database, expressed as percentage of GDP, in order to reflect economic growth in countries. ${ }^{11}$

Secondly, we do not possess enough data to cover all countries of the world. In order to obtain a consistent dataset on CIs and FDI stock and exclude the influence of the global crisis (2008-2012), ${ }^{12}$ we could select data only for 94 countries for the years 1998-2007

10 Wald F-tests are used to estimate the statistical significance of a group of explanatory variables in the model.

11 Alternatively, it is possible to use FDI stock per capita. FDI stock in terms of GDP, however, allows us to reflect economic development, which can exceed the growth of FDI stock in terms of population in some of the countries, and thus correct for overstatement of importance.

12 During the crisis there was a decline in FDI flows in the world, which can bias the results (e.g. in the form of a decrease in FDI stock which does not influence corruption). 
(in total, 940 observations) $)^{13}$ where we still performed interpolations/extrapolations for COC for the years 1999 and 2001 (before 2002 the World Bank conducted bi-annual surveys) and for CPI for individual years (the structure of countries in Transparency International's surveys is variable in time).${ }^{14}$ The time series are therefore short, which may lead to lower estimate quality (the problem is addressed below). The list of countries can be found in Appendix.

Our dataset therefore represents a sample, which may not be an accurate representation of the entire population. Unfortunately, at present, there are no widely used statistical methods to solve this problem with the exception of several, e.g. Kelley and Maxwell (2003) estimators. Thus, in this paper, we attempt to solve it through traditional statistical methods:

a) Using random effects models instead of fixed effects (the sample is in fact randomly created) and

b) Including two factors in regression models, which we assume to reflect the differences between countries: the economic level, measured by real GDP per capita, and cultural dimension expressed as geographic location in one of thirteen regions (Western Europe, Central and Eastern Europe, Eastern Europe, North America, Central America and Caribbean, Latin America, Middle/Central Asia, Southeastern Asia, Other Asia, Middle East, Northern Africa, Other Africa and Pacific expressed as 12 dummy variables). ${ }^{15}$

These corrections enable us to use the original sample without excluding high or low corruption countries or dividing it into two groups, as in the study of Caetano and Caleiro (2005). We also apply Newey-West (1987) standard errors estimator (HAC) in pooled panel regression models in order to provide for heteroscedasticity and improve the estimates' quality, i.e. to compensate for the length of the paneled time series.

\section{Results}

Table 3 compares characteristics of distributions of the three CIs (CPI, COC and FFC) and assesses their mutual correlation with the help of Pearson correlation coefficients (PCC).

From this table it is perceivable that all the three CIs have similar mean values (around 5, 0 and 50), median values (somewhat slightly below 5, 0 and 50) and variation (values of the C. V. are around 50\% except for COC which has different measurement units). All the three distributions are positively skewed (more numerous are countries with lower CI values, i.e. higher corruption) and platykurtic (U-shaped, having two peaks: for high and very low corruption), thus not normal (Gaussian); see the example in Figure 1 below.

13 Values before 1998 were not available for some of the CIs, mainly CPI.

14 Due to the high correlation between the three CIs (see below), we estimated missing values with the help of other CIs, mainly FFC as the most complete dataset, using averages and regression analysis.

15 Western Europe is selected as the default geographic region. Russia is included in the Eastern Europe, Turkey in the Middle East and Australia and New Zealand in the Pacific. 
Table 3

Distributions of the Cls and Their Mutual Correlation

\begin{tabular}{|l|c|r|r|}
\hline Indicator & \multicolumn{1}{|c|}{ CPI } & \multicolumn{1}{c|}{ COC } & \multicolumn{1}{c|}{ FFC } \\
\hline Value range (original) & $1-10$ & $-2.5-2.5$ & $0-100$ \\
\hline Mean value & 4.7587 & 0.2929 & 47.6230 \\
\hline Median value & 4.0000 & -0.0068 & 41.0000 \\
\hline Minimum & 1.0000 & -1.4455 & 7.0000 \\
\hline Maximum & 10.000 & 2.6419 & 100.0000 \\
\hline Standard deviation & 2.3588 & 1.0788 & 23.6340 \\
\hline Coef. of variation & 0.4957 & 3.6836 & 0.4963 \\
\hline Skewness (3rd moment) & 0.6955 & 0.5752 & 0.6489 \\
\hline Kurtosis (4 ${ }^{\text {th }}$ moment) & -0.7667 & -0.8702 & -0.7480 \\
\hline Within st. deviation & 0.3962 & 0.1855 & 5.2182 \\
\hline Between st. deviation & 2.3399 & 1.0695 & 23.2210 \\
\hline Mutual correlation, PCC & & & \\
\hline CPI & 1.0000 & 0.9789 & 0.9720 \\
\hline COC & & 1.0000 & 0.9604 \\
\hline FFC & & 1.0000 \\
\hline
\end{tabular}

Note: The maximum value of $\mathrm{COC}$ slightly exceeds its original value range as a result of interpolations. Source: self-prepared.

Figure 1

\section{Distribution of CPI in Comparison with the Normal Distribution}

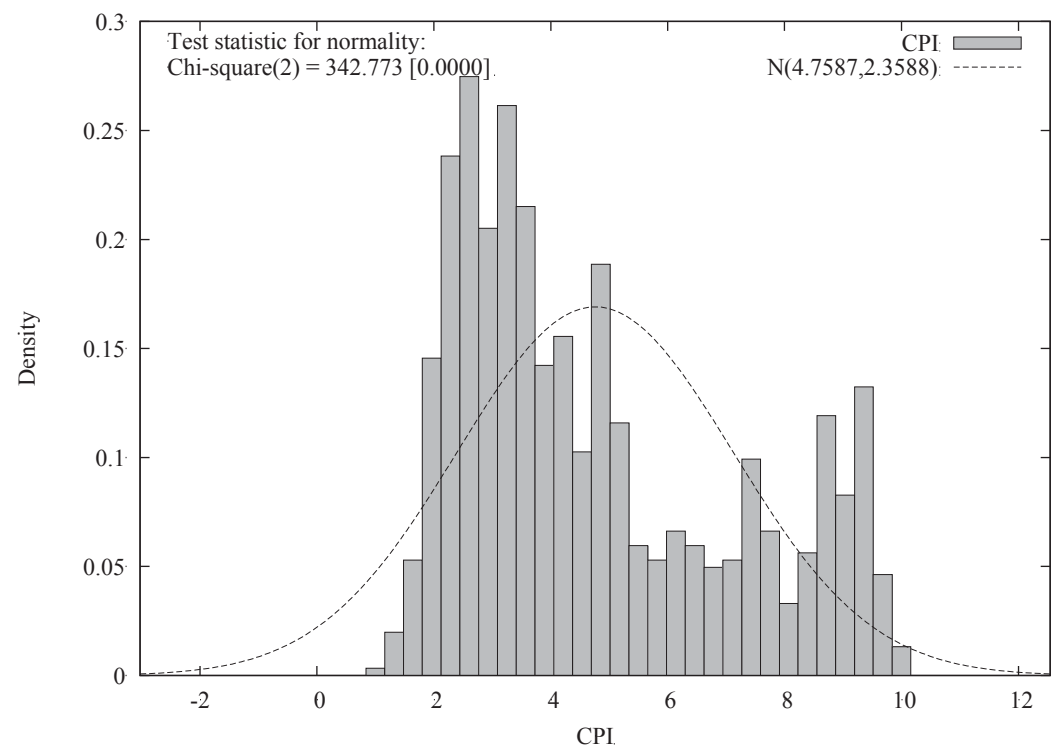

Note: $X^{2}(2)$ - statistic is greater than the $1 \%$ percentile for 2 degrees of freedom, thus CPI is not normally distributed at the $99 \%$ probability level.

Source: Gretl, self-prepared. 
It is also perceivable that variation between cross-sections is significantly greater than within cross-sections, which makes the sample significantly heterogeneous and requires the use of resampling, break-up into groups or corrections for its adjustment (as in our approach).

Nevertheless, as all the three CIs are mutually correlated of more than $95 \%$ (which actually proves that surveys conducted by different institutions can estimate corruption relatively accurately), ${ }^{16}$ it is sufficient to concentrate only on one $\mathrm{CI}$ in future calculations. We will focus our attention on the Heritage Foundation's FFC index, as the most complete dataset (whose values did not need to be interpolated). Others will be used as additional verification.

\section{Stationarity Condition (SC)}

The results of the Choi meta-tests based on ADF and KPSS tests for 94 countries are presented for FFC and additionally for CPI and COC in Table 4.

Table 4

Results of Choi meta-tests for Cls

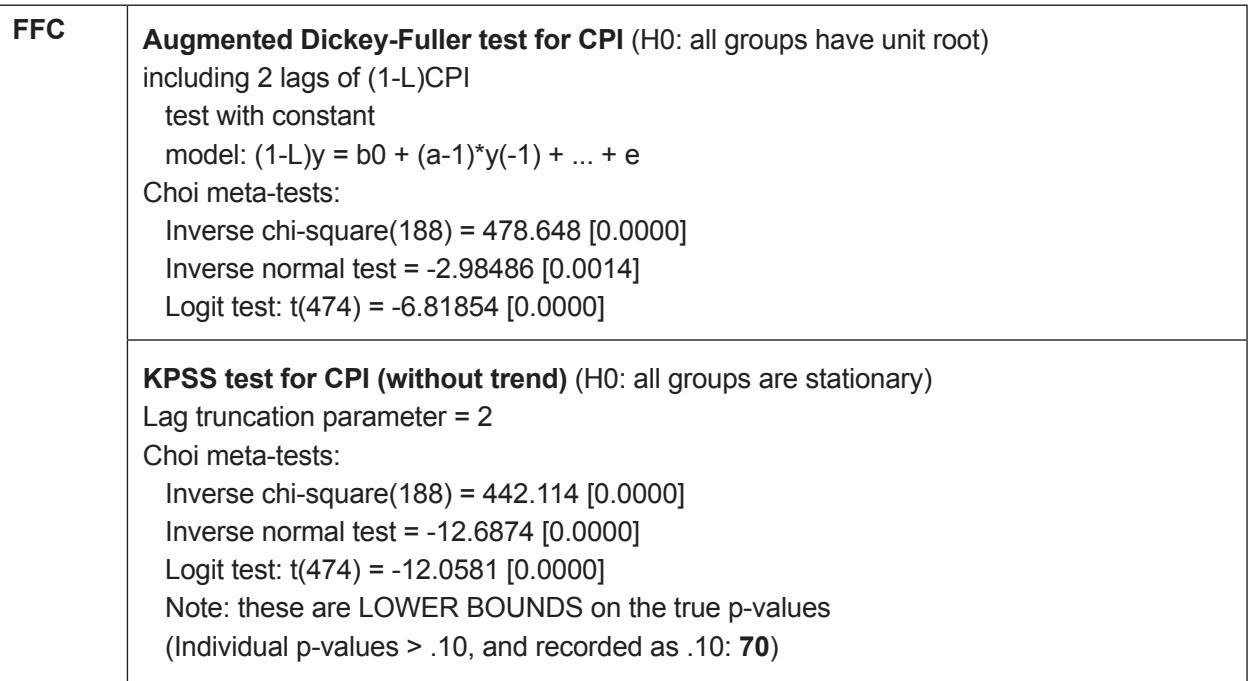

16 In this respect, we use the term "accurately" only in assessing the datasets' variation. 
Table 4 - continuation

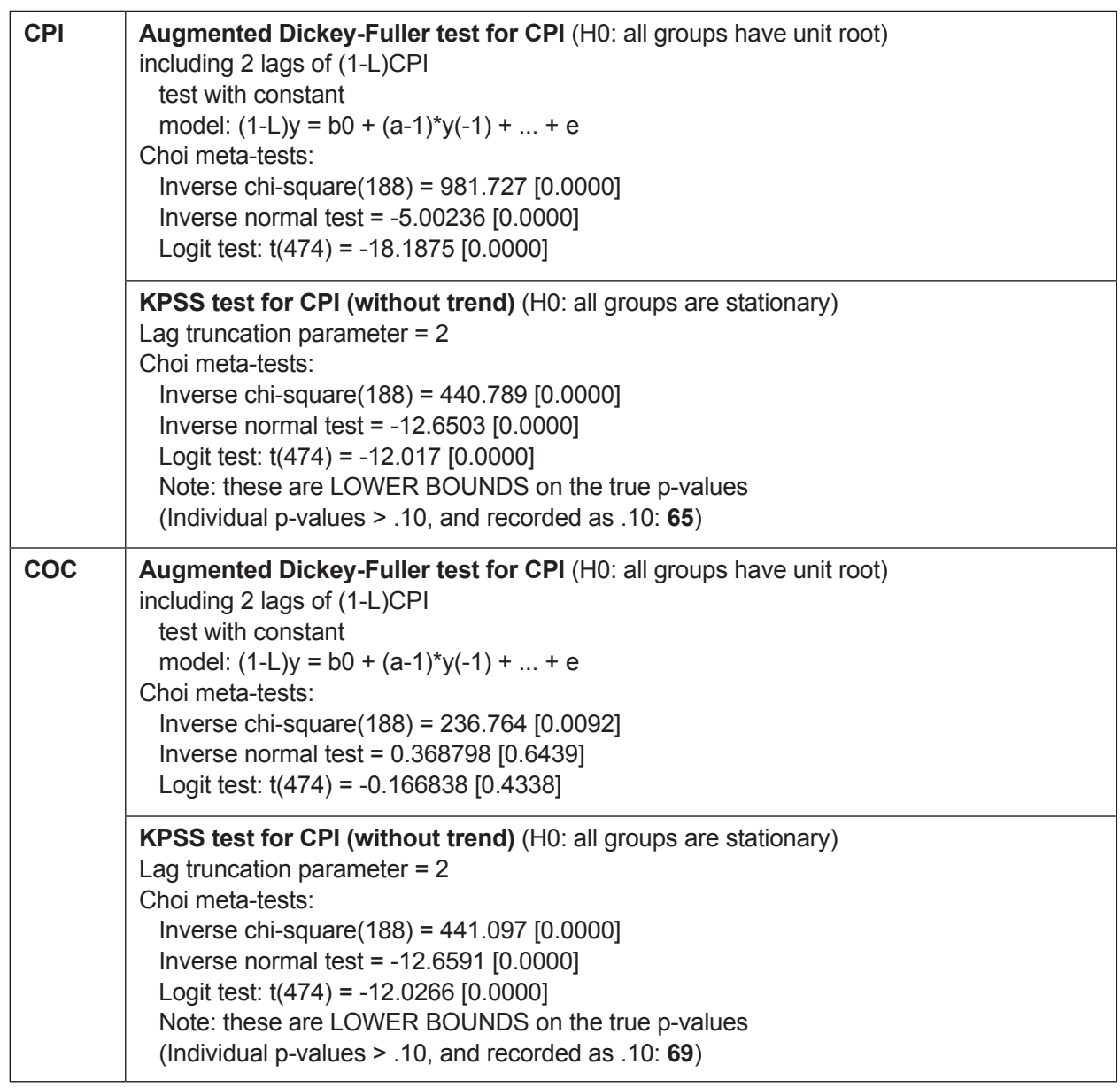

Note: The number of lags was selected with the help of the Schwert (1988, p. 7) criterion for yearly data: $\operatorname{lnt}\left(4(T / 10)^{\wedge} .25\right)$, where Int is integer function and $T$ is the number of years (in our case $T=10$ ).

Source: Gretl, self-prepared.

The Choi meta-tests show that FFC (and also CPI and COC) is heterogeneous in terms of integration, but mostly stationary. The share of stationary time series in the panel datasets is $70 / 94$, i.e. $74.5 \%(69.1 \%$ and $73.4 \%) .{ }^{17}$ The SC criterion is not strictly met according to our definition, however, the share may be sufficient for this hypothesis to be still true, if co-integration relationships between CI and FDI stock time series are not numerous.

17 As the results are approximately the same, we will refrain from using CPI and COC in further calculations. 


\section{Weak correlation and no causality conditions (WCC and NCC)}

Table 5 presents the results of Choi meta-tests for FDI stock based on ADF and KPSS tests for 94 countries.

Table 5

Results of Choi meta-tests for FDI Stock

\begin{tabular}{|c|c|}
\hline \multirow{2}{*}{ FDI stock } & $\begin{array}{l}\text { Augmented Dickey-Fuller test for CPI (H0: all groups have unit root) } \\
\text { including } 2 \text { lags of }(1-\mathrm{L}) \mathrm{CPI} \\
\text { test with constant } \\
\text { model: }(1-\mathrm{L}) \mathrm{y}=\mathrm{b} 0+(\mathrm{a}-1)^{\star} \mathrm{y}(-1)+\ldots+\mathrm{e} \\
\text { Choi meta-tests: } \\
\text { Inverse chi-square }(188)=371.485[0.0000] \\
\text { Inverse normal test }=8.50046[1.0000] \\
\text { Logit test: } \mathrm{t}(474)=7.72568[1.0000]\end{array}$ \\
\hline & $\begin{array}{l}\text { KPSS test for CPI (without trend) (H0: all groups are stationary) } \\
\text { Lag truncation parameter }=2 \\
\text { Choi meta-tests: } \\
\text { Inverse chi-square }(188)=472.289[0.0000] \\
\text { Inverse normal test }=-13.5327[0.0000] \\
\text { Logit test: } t(474)=-12.9961[0.0000] \\
\text { Note: these are LOWER BOUNDS on the true p-values } \\
\text { (Individual } p \text {-values }>.10 \text {, and recorded as } .10: 27)\end{array}$ \\
\hline
\end{tabular}

Note: The number of lags was selected with the help of the Schwert (1988, p. 7) criterion for yearly data: $\operatorname{Int}\left(4(T / 10)^{\wedge} .25\right)$, where Int is integer function and $T$ is the number of years (in our case $T=10$ ).

Source: Gretl, self-prepared.

The Choi meta-tests show that FDI stock is also heterogeneously integrated, but mostly non-stationary. The share of non-stationary time series in the panel datasets is 67 / 94, i.e. $71.3 \%$. According to the probability theory, there is therefore a $(1-0.745) * 0.713 *$ $* 100 \%=18.2 \%$ chance that time-series in FFC and FDI stock are simultaneously non-stationary. The probability of a co-integration relationship (of stationarity of residuals) is thus even lower, e.g. $9.1 \%$. (if the probability of residuals being stationary is $50 \%$ ).

This means that there is a $81.8-90.9 \%$ probability that time series in the datasets fluctuate around a certain value or their mutual relationship is spurious.

To check the possible co-integration relationship in part of the time series (the WCC hypothesis for a part of datasets - it is impossible to perform an overall evaluation due to the heterogeneity in integration), we reduce the FFC and FDI stock datasets to only non-stationary time series, according to the results of ADF and KPSS tests (in total 20, see Appendix).

The results of the random effects model, see (2), extended to the real GDP per capita and geographical location dummies variables (left after the reduction) is presented in Table 6. 
Table 6

\section{Results of the Random Effects (GLS) Model}

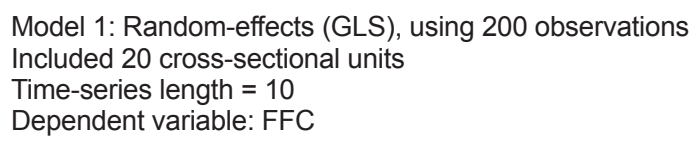

\begin{tabular}{|l|r|r|r|c|}
\hline & \multicolumn{1}{|c|}{ coefficient } & \multicolumn{1}{c|}{ std. error } & \multicolumn{1}{c|}{ t-ratio } & \multicolumn{1}{c|}{ p-value } \\
\hline const. & 29.7809 & 6.55264 & 4.545 & \multicolumn{1}{c|}{$9.76 \mathrm{e}-06^{* * *}$} \\
\hline FDI_stock & -0.00570253 & 0.0138171 & -0.4127 & \multicolumn{1}{c|}{0.6803} \\
\hline RGDPpc & 0.00125704 & 0.000185456 & 6.778 & $1.49 \mathrm{e}-10^{* * *}$ \\
\hline Dummy_CE_Europe & 1.32112 & 6.04086 & 0.2187 & 0.8271 \\
\hline Dummy_C_America & 10.0064 & 7.36604 & 1.358 & 0.1759 \\
\hline Dummy_L_America & -1.69396 & 8.50816 & -0.1991 & 0.8424 \\
\hline Dummy_SE_Asia & 28.6954 & 7.01038 & 4.093 & $6.28 \mathrm{e}-05^{\text {*** }}$ \\
\hline Dummy_O_Asia & 13.5347 & 6.27182 & 2.158 & $0.0322^{\text {** }}$ \\
\hline Dummy_N_Africa & 8.70431 & 8.74014 & 0.9959 & 0.3206 \\
\hline Dummy_O_Africa & 3.74515 & 7.35212 & 0.5094 & 0.6111 \\
\hline
\end{tabular}

\begin{tabular}{|l|r|l|l|}
\hline Mean dependent var. & 50.91500 & S.D. dependent var & 20.52301 \\
\hline Sum squared resid. & 10439.89 & S.E. of regression & 7.393179 \\
\hline Log-likelihood & -679.2949 & Akaike criterion & 1378.590 \\
\hline Schwarz criterion & 1411.573 & Hannan-Quinn & 1391.938 \\
\cline { 1 - 3 }
\end{tabular}

'Within' variance $=32.1667$

'Between' variance $=34.0389$

theta used for quasi-demeaning $=0.692591$

Breusch-Pagan test -

Null hypothesis: Variance of the unit-specific error $=0$

Asymptotic test statistic: Chi-square $(1)=77.921$

with $p$-value $=1.07243 \mathrm{e}-18$

Test for omission of variables (Wald test) -

Null hypothesis: parameters are zero for the variables RGDPpc, Dummy_CE_Europe,

Dummy_C_America, Dummy_L_America, Dummy_SE_Asia, Dummy_O_Asia, Dummy_N_Africa, Dummy_O_Africa

Test statistic: $F(8,190)=23.0584$

with $p$-value $=P(F(8,190)>23.0584)=1.90972 \mathrm{e}-24$

Note: Hausman test was omitted due to the use of sample. Its p-value was 0.037 (which is above 0.01 criterion). Source: Gretl, self-prepared.

From the table, it is perceivable that a) random effects are applicable according to the Breusch-Pagan (1979) test, i.e. there are significant panel effects in the dataset at the $99 \%$ probability level, b) the variance between groups is not greater than within groups (the sample is not significantly heterogeneous), c) the correction variables are significant according to the Wald (1943) F-test and d) the coefficient estimate of the FDI 
stock is not statistically significant (which proves the WCC hypothesis), weak and even has a negative sign (i.e. an increase in FDI stock increases corruption, as lower values of CIs represent high corruption) and e) the most important factor influencing FFC is the real GDP per capita.

The residuals of the model are normally distributed $\left(\chi^{2}(2)\right.$ - statistic is 1.328 with p-value of 0.515$)$, but not homogenously stationary, see Table 7.

Table 7

Results of Choi meta-tests for Residuals of the Random Effects Model

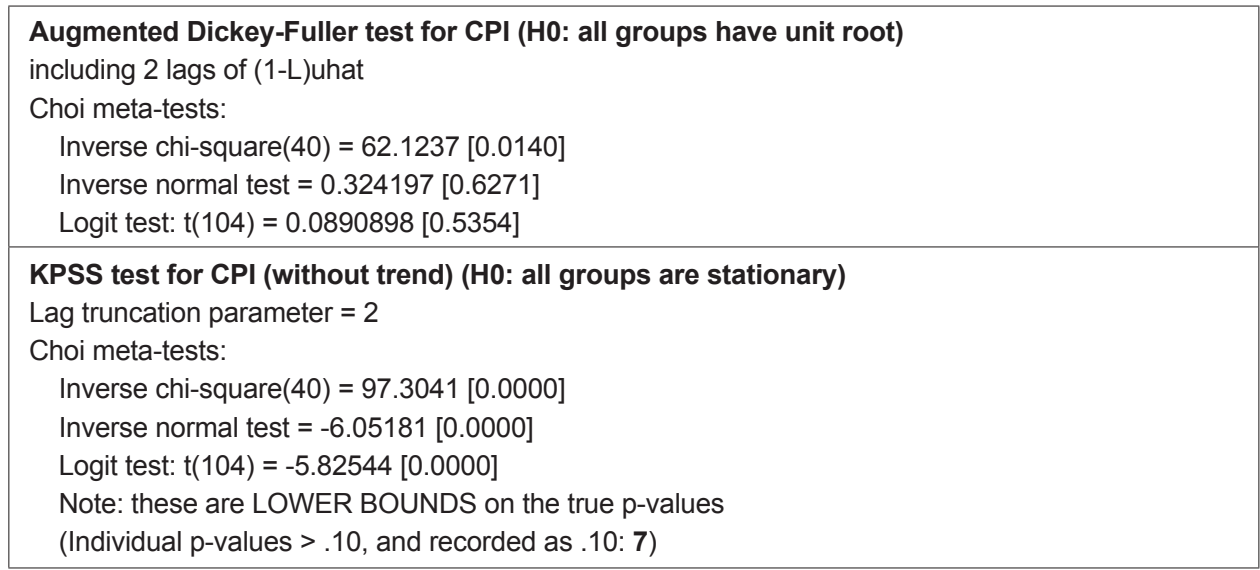

Note: The number of lags was selected with the help of the Schwert (1988, p. 7) criterion for yearly data: $\operatorname{lnt}\left(4(T / 10)^{\wedge} .25\right)$, where Int is integer function and $T$ is the number of years (in our case $T=10$ ).

Source: Gretl, self-prepared.

The co-integration relationship thus exists only for 13 countries and Choi meta-tests point to the almost homogenous non-stationarity of residuals.

Therefore, we can consider the SC hypothesis to be valid for 81 countries out of 94 $(86.2 \%)$ and the WCC hypothesis - for the rest (13.8\%). This automatically proves the NCC hypothesis without the need of using Granger causality tests, see (4). In fact, we can consider SC to be roughly valid for the whole dataset. And, as all three hypotheses are proved, it is possible to state that, based on our sample, there seems to be no significant (systematic) relationship between corruption and FDI at the world level, which confirms the findings of Harrison (2003).

\section{Can Improvement in Corruption Attract More FDI?}

The final question, which is important to ask, is whether there is certain causality between decreasing levels of corruption and increases in FDI (in the opposite direction compared to our analysis). From the theoretical point of view, the total improvement in business environment and good economic results indeed attract more FDI. However, our econometric verification does not prove significant relationship between corruption and FDI. 
The changes in the levels of corruption and FDI, according to our results, are, most likely, caused by some third factors, e.g. the real GDP per capita (see the strong relationship between it and FFC for 13 countries), or are of a cyclical/repeated character (as CI are mostly stationary), e.g. in expansion phases of the business cycle. More research on this matter is, however, needed to draw reliable conclusions.

\section{Conclusions}

In this paper, we attempted to present a theoretical explanation and econometric verification of the weak relation between corruption (as a representation of the political environment) and FDI inflows in countries. After a theoretical explanation of compensation effects (investment incentives and cultural influences), we performed an econometric study using three theoretically-based hypotheses: that corruption perception indicator is a stationary variable (SC), that the co-integration relationship between corruption and foreign direct investment stock is statistically weak (WCC) and that changes in foreign direct investment stock do not Granger cause changes in corruption (NCC).

All hypotheses were proved on the panel data sample of 94 countries for the years 1998-2007. Increases in FDI stock therefore do not seem to improve the political environment of countries at the world level and vice versa. Used time series were, however, very short, which may affect the econometric results.

\section{Appendix:}

List of countries in the original dataset (94): Argentina, Australia, Austria, Belarus, Belgium, Bolivia, Botswana, Brazil, Bulgaria, Cameroon, Canada, Chile, China, Colombia, Costa Rica, Côte-d'Ivoire, Croatia, the Czech Republic, Denmark, Dominican Republic, Ecuador, Egypt, El Salvador, Estonia, Ethiopia, Finland, France, Germany, Ghana, Greece, Guatemala, Honduras, Hong Kong, Hungary, Iceland, India, Indonesia, Ireland, Israel, Italy, Jamaica, Japan, Jordan, Kazakhstan, Kenya, Latvia, Lithuania, Luxembourg, Malawi, Malaysia, Mauritius, Mexico, Moldova, Morocco, Namibia, Netherlands, New Zealand, Nicaragua, Nigeria, Norway, Pakistan, Panama, Paraguay, Peru, Philippines, Poland, Portugal, Romania, Russia, Senegal, Singapore, Slovak Republic, Slovenia, South Africa, South Korea, Spain, Sweden, Switzerland, Taiwan, Tanzania, Thailand, Trinidad \& Tobago, Tunisia, Turkey, Uganda, Ukraine, the United Kingdom, Uruguay, USA, Uzbekistan, Venezuela, Vietnam, Zambia and Zimbabwe.

List of countries in the reduced dataset (20): Austria, Bulgaria, Colombia, Costa Rica, Côte-d'Ivoire, Greece, Hong Kong, Iceland, Jamaica, Latvia, Lithuania, Morocco, Poland, Romania, Singapore, Slovenia, South Africa, Spain, Taiwan and Zambia. 


\section{References}

Al-Sadig, A. (2009), "The Effects of Corruption on FDI Inflows." Cato Journal, Vol. 29, No. 2, pp. 267-294.

Arlt, J. (1997), "Regresní analýza nestacionárních ekonomických časových řád." Politická ekonomie, Vol. 45, No. 2, pp. 281-289.

Arlt, J. (1999), Moderní metody modelování ekonomických časových řad. Praha: Grada Publishing.

Benáček, V. (2010), Is the Czech Economy a Success Story? The Case of CzechInvest: The Strategic Promotion Agency in Czech Industrial Restructuring. Santiago: ECLAC.

Breusch, T. S., Pagan, A. R. (1979), "Simple Test for Heteroscedasticity and Random Coefficient Variation". Econometrica, Vol. 47, No. 5, pp. 1287-1294.

Caetano, J., Caleiro, A. (2005), "Corruption and Foreign Direct Investment: What Kind of Relationship Is There?" Portugal: University of Évora, Department of Economics, Economics Working Papers No. 18.

Caves, R. E. (1982), Multinational Enterprise and Economic Analysis. Cambridge: Cambridge University Press.

Choi, I. (2001), "Unit Root Tests for Panel Data." Journal of International Money and Finance, Vol. 20, No. 2, pp. 249-272.

Dickey, D. A., Fuller, W. A. (1979), "Distribution of the Estimators for Autoregressive Time Series with a Unit Root." Journal of the American Statistical Association, Vol. 74, No. 366, pp. 427-431.

Dunning, J. H. (1998), "The Eclectic Paradigm of International Production: A Restatement and Some Possible Extensions." Journal of International Business Studies, Vol. 19, No. 1, pp. 1-31.

Dupal, J. (2009), "Účinky prímých zahraničních investic podpořených investičními pobídkami v kontextu svých pozitiv a negativ." University of Economics, Prague. PhD thesis.

Engle, R., Granger, C. W. J. (1987), "Co-Integration and Error Correction: Representation, Estimation, and Testing." Econometrica, Vol. 55, No. 2, pp. 251-276.

Evan, T. (2006), “K některým otázkám politické ekonomie prímých zahraničních investic." Prague: University of Economics, Ph.D. thesis.

Evan, T. (2010), "Some Issues of Political Economics of Multinational Corporations." Acta Oeconomica Pragensis, Vol. 18, No. 4, pp. 32-43.

Granger, C. W. J. (1969), "Investigating Causal Relations by Econometric Models and Cross-spectral Methods." Econometrica, Vol. 37, No. 3, pp. 424-438.

Harrison, M. J. (2003), "Can Corrupt Countries Attract Foreign Direct Investment? A Comparison of FDI Inflows Between Corrupt and Non-Corrupt Countries." International Business and Economic Research Journal, Vol. 2, No. 9, pp. 93-100.

Hood, M. V., Kidd, Q., Morris, I. L. (2006), "Two Sides of the Same Coin? Employing Granger Causality Tests in a Panel Framework." Mimeo, University of Maryland.

Hurlin C. (2004a), "A Note on Causality Tests in Panel Data Models With Random Coefficients." Mimeo, University of Orleans.

Hurlin C. (2004b), "Testing Granger Causality in Heterogenous Panel Data Models with Fixed Coefficients." University of Orleans Working Paper.

Hurlin C., Venet, B. (2001), "Granger Causality Tests in Panel Data Models with Fixed Coefficients." Université Paris IX Dauphine, Working Paper No. Eurisco 2001-09.

Hurlin, C., Dumitrescu, E. (2012), "Testing for Granger Non-causality in Heterogeneous Panels." Economic Modelling, Vol. 29, No. 4, pp. 1450-1460.

Hymer, S. H. (1960), The International Operations Of National Firms: A Study of Direct Foreign Investment. Cambridge, Massachusetts (USA): MIT Press.

Hymer, S. H. (1976), The International Operations of National Firms: A Study of Direct Investment. Cambridge: Cambridge University Press.

Kao, C. (1999), "Spurious Regression and Residual-based Tests for Cointegration in Panel Data." Journal of Econometrics, Vol. 90, No. 1, pp 1-44. 
Kelley, K., Maxwell, S. E. (2003), "Sample Size for Multiple Regression: Obtaining Regression Coefficients That Are Accurate, not Simply Significant." Psychological Methods, Vol. 8, No. 3, pp. 305-321.

Kindleberger, C. P. (1969), American Business Abroad: Six Lectures on Direct Investment. New Haven and London: Yale University Press.

Kwiatkowski, D., Phillips, P. C. B., Schmidt, P., Shin, Y. (1992), "Testing the Null Hypothesis of Stationarity against the Alternative of a Unit Root." Journal of Econometrics, Vol. 54, No. 1-3, pp. 159-178.

Lee, J. Y., Mansfield, E. (1996), "Intellectual Property Protection and U.S. Foreign Direct Investment." Review of Economics and Statistics, Vol. 78, No. 2, pp. 181-186.

Newey, W. K., West, K. D. (1987), "A Simple, Positive Semi-definite, Heteroskedasticity and Autocorrelation Consistent Covariance Matrix." Econometrica, Vol. 55, No. 3, pp. 703-708.

Petříček, V. (2003), Vývoj investičního prostředí v České republice. Praha: Corona.

Schwert, G. W. (1988), "Tests for Unit Roots: A Monte Carlo Investigation." National Bureau of Economic Research, NBER Technical Working Papers No. 0073.

Vernon, R., Wells, L. T. (1972), The Economic Environment in International Business. Boston: Prentice-Hall.

Vijayakumar, N., Sridharan, P., Rao, K. C. S. (2010), "Determinants of FDI in BRICS Countries: A Panel Analysis." International Journal of Business Science and Applied Management, Vol. 5, No. 3, pp. 1-13.

Wald, A. (1943), "Tests of Statistical Hypotheses Concerning Several Parameters when the Number of Observations Is Large." Transactions of the American Mathematical Society, Vol. 54, No. 3 , pp. 426-482. 